\title{
Peace Counseling Approach (PCA) to Reduce Negative Aggressive Behavior of Students
}

\author{
Wahyu Nanda Eka Saputra ${ }^{1}$, Agus Supriyanto ${ }^{1}$, Budi Astuti ${ }^{2}$, Yulia Ayriza ${ }^{2}$, Sofwan Adiputra ${ }^{3, *}$, \\ Augusto Da Costa ${ }^{4}$, Ediyanto ${ }^{5}$
}

\author{
${ }^{1}$ Department of Guidance and Counseling, Universitas Ahmad Dahlan, Indonesia \\ ${ }^{2}$ Department of Guidance and Counseling, Universitas Negeri Yogyakarta, Indonesia \\ ${ }^{3}$ Department of Guidance and Counseling, Universitas Muhammadiyah Pringsewu, Indonesia \\ ${ }^{4}$ Department of Psychology, Instituto Superior Cristal, Timor-Leste \\ ${ }^{5}$ Graduate School for International Development and Cooperation, Hiroshima University, Japan
}

Received December 7, 2019; Revised January 3, 2020; Accepted January 13, 2020

Copyright $\bigcirc 2020$ by authors, all rights reserved. Authors agree that this article remains permanently open access under the terms of the Creative Commons Attribution License 4.0 International License

\begin{abstract}
Negative aggression behavior arises among students so an approach is needed to reduce it. Peace Counseling Approach (PCA) is an approach that develops the potential of every human being without causing violence. Peace actually resides in the human mind. Therefore, training is conducted so that the counselee has a peaceful mindset. Aggression behavior in adolescents is still a complex problem behavior. Negative aggression behavior, is the behavior of someone who intentionally hurt others both physically and psychologically using certain media. The purpose of this study was to examine the effectiveness of PCA in reducing the aggressive behavior of students. The study design uses true experimental randomized pre and post test control group design. The subjects of this study were vocational high-school students in Yogyakarta who had very high aggression behavior. Determination of research subjects using random assignment techniques. The data-collection tool used to measure aggressive behavior is the scale of aggressive behavior. The data analysis technique used in this study was the independent $t$-test. The results of this study indicate that aggression behavior can decrease significantly after being given a PCA intervention. Students are able to develop peaceful thoughts that can minimize the desire of students to behave in aggression.
\end{abstract}

Keywords Peace Counseling Approach, Aggressive Behavior, Peace Education

\section{Introduction}

Peace education as a theoretical basis of Peace Counseling Approach (PCA) is a holistic process to develop the potential of every human being without having to bring up violence (Shapiro, 2015). Aggression acts become a problem that needs to be intervened. Moreover, multicultural aspects become a variable that has the potential to trigger aggression behavior (Strohmeier \& Spiel, 2003). Peace education must help build a vision of a peaceful future in a world where diversity of, and plurality can be celebrated without fear and threats (Cabezudo \& Haavelsrud, 2013).

Some countries have begun implementing peace education. In Thailand's peace education, programs are becoming programs in education that are intensively implemented because of the high social conflicts that occur to bring up high levels of quality and quantity of aggression behavior (Englehart, 2008; Yusuf \& Schmidt, 2006). Whereas in Japan, research findings reveal that students in secondary schools who have experienced peace education are more self-reliant, sensible, and independent in understanding social problems (Millon \& Kawano, 2016).

In Indonesia, peace education is a solution to reduce aggression that appears in students. Research results from Saputra \& Handaka (2017) state that PCA is a counseling model that can be used by counselors to develop students' peaceful thoughts, so that they are expected to be able to regulate student emotions and reduce the desire to behave in aggression.

The results showed that many aggressive problems occur among adolescents, especially students. Research shows that at least $72.16 \%$ of student's commit crimes involving physical violence, while the remaining $27.84 \%$ of students tend to commit crimes that do not involve physical violence (Shelton, Sampl, Kesten, Zhang, \& Trestman, 2009).

Several studies have shown that many aggressive problems occur among adolescents, especially students. 
Research shows that at least $72.16 \%$ of student's commit crimes involving physical violence, while the remaining $27.84 \%$ of students tend to commit crimes that do not involve physical violence (Shelton, Sampl, Kesten, Zhang, \& Trestman, 2009). Another study in Yogyakarta, showed that junior high-school students in Yogyakarta had aggression in the very high category of $1 \%$, high category $13 \%$, medium category $37 \%$, low category $43 \%$, and very low category 6\% (Alhadi, Purwadi, Muyana, Saputra, \& Supriyanto, 2018).

While the Vocational High School level in the city of Yogyakarta, aggressive behavior showed a very high category by $5 \%$, a high category by $26 \%$, a moderate category by $40 \%$, a low category by $21 \%$, and a very low category by $8 \%$ (Saputra, 2018). The results showed that there were no significant differences in the level of aggressive behavior between men and women (Saputra, Hanifah, \& Widagdo, 2017).

In Indonesia, the concept of counseling is integrated with educational programs at the primary, secondary and higher levels. The concept of peace education can be derived from the implementation of counseling, which in this study is called PCA. One of the main objectives of the PCA is to develop a peaceful mind in students who are equipped to suppress aggression in themselves.

The use of PCA to reduce aggression behavior is not without reason. This approach using the roots of peace education can be a counselee's means of learning to think peacefully. Peace itself is actually in the human mind (Anand, 2014). Therefore, the intervention is carried out so that the counselee has a peaceful mindset (Liu et al., 2015). This peaceful mindset can reduce the desire of adolescents to hurt others intentionally, both physically and verbally.

\section{Literature Review}

Aggression behavior is conceptually defined as the tendency of someone who consciously behaves to hurt others, both physically and verbally, through various means, as a response to the situation (Noorfitriyani, Gunawan, \& Kertawidana, 2018). It triggers aggression behavior not only from individual factors, but the attribution and cognitive management of events also influence it (Berkowitz, 2012). Some things like that ultimately encourage a person's tendency to do aggression when in an unpleasant situation.

This behavior occurs due to certain factors. Video games and television shows that show violence can trigger the emergence of aggressive behavior in children and adolescents (Breuer, Vogelgesang, Quandt, \& Festl, 2015; Qayyum, Malik, Iqbal, Haq, \& Malik, 2013). Adolescent perceptions about family and school environment influence the emergence of these behaviors (López, Pérez, Ochoa, \& Ruiz, 2008). In addition, emotional stability and factors such as low openness, friendliness, self-awareness can also trigger aggressive behavior (Aniței, Chraif, Burtaverde, \& Mihaila, 2014).

Aggression behavior itself is divided into three types, namely; openly aggressive, relational aggressive, and aggressive instrumental (López, Pérez, Ochoa, \& Ruiz, 2008). First, overtly aggressive which is a type of behavior that acts directly and real violence (for example, hitting and pushing). Second, aggressive relational, a form of behavior that harms others through manipulation of interpersonal relationships (for example, spreading lies and slandering news); Third, aggressive instrumental, namely the behavior carried out by the aggressor to achieve a direct goal (for example, hitting a colleague to get money).

This behavior can be understood in the form of verbal and nonverbal behavior (Yusuf, 2005). Verbal form is shown by the behavior that says rude words, while the nonverbal form is shown by performing physical actions that both aim to intentionally hurt others.

Some literature states that aggressive behavior is closely related to violence (Nazmie, Nebi, \& Zylfije Bekim, 2013) and anger (Edwards, Warren, Tubré, Zyphur, \& Hoffner-Prillaman, 2013; Kovácsová, Rošková, \& Lajunen, 2014).

So that PCA is expected to help to reduce student aggression. In the PCA, there are four interrelated components, namely strength, harmony, positivity, and lifestyle (Floody, 2014). The power component has to do with spirituality and the search for meaning. The component of harmony is related to acceptance or wisdom, anger management, forgiveness, compassion, and meditation. The positive component is related to happiness or subjective well-being, emotions, humor, gratitude, and problem solving. The lifestyle component is related to life for today, health psychology, simplicity, respect for nature, social networking, contributing to society, and serving leadership.

Peace education can truly develop ethical, social and moral awareness so that humanity can begin to wish for a more peaceful world (Duckworth, 2006). Peace that develops in schools can create a conducive school climate, thus encouraging students to be able to actualize themselves to the maximum. This is one of the maximum stimuli for academic achievement of students (Haynes, Emmons, \& Ben-Avie, 1997; Kutsyuruba, Klinger, \& Hussain, 2015; MacNeil, Prater, \& Busch, 2009; Pong \& Zeiser, 2012).

PCA was developed using the basic theory of peace education and set up in counseling sessions (Saputra, Hanifah, \& Widagdo, 2017; Saputra \& Handaka, 2017). Peace itself has three domains, namely (1) synonyms for stability or balance; (2) the absence of organized collective violence, and (3) synonyms for all other good things in the world community, especially cooperation between human groups without violence (Galtung, 1967).

Counselors who implement PCA seeks to instill the 
values of peace in the minds of every human being (Anand, 2014). Emotional stability that is embedded in students can promote emotional stability to minimize the appearance of aggressive behavior. The purpose of this study was to examine the effectiveness of PCA in reducing the aggressive behavior of students.

\section{Methods}

\subsection{Research Design}

This PCA research design uses true experimental design. This design has the characteristics of involving randomly assigned experimental and control groups. The first group was treated according to the design of the PCA intervention (experimental group), and the second group was given conventional counseling intervention (control group). The type of true experimental design used was randomized pre and post test control group design.

\subsection{Data Collection}

The data-collection tool used is a aggressive behavior scale (ABS). This scale consists of 38 items with a validity level in the range of 0.21 to 0.56 and has a reliability level of 0.825 in the high category. This scale was developed using four aspects, namely physical aggression, verbal, anger, and hostility (Buss \& Perry, 1992).

Table 1. Aggressive Behavior Scale (ABS) indicator

\begin{tabular}{|c|l|}
\hline Aspect & \multicolumn{1}{c|}{ Indicator } \\
\hline \multirow{2}{*}{ Physical } & Deliberately injuring others individually \\
\cline { 2 - 3 } & Deliberately injuring others as a group \\
\hline \multirow{2}{*}{ Verbal } & Hurting others in the form of verbal rejection \\
\cline { 2 - 2 } & Verbally hurt others' feelings \\
\hline \multirow{2}{*}{ Anger } & Vent anger to others intentionally \\
\cline { 2 - 2 } & Hold high-pitched conversations with others \\
\hline \multirow{2}{*}{ Hostility } & Threats to others who do not like \\
\cline { 2 - 2 } & It expresses hatred of others intentionally \\
\hline
\end{tabular}

\subsection{Subject of Study}

The subjects of this study were students of Vocational high School Muhammadiyah 1 Yogyakarta and Muhammadiyah 3 Yogyakarta that had very high levels of aggression. The random assignment technique is used in determining subjects. Subject groups participating in the study were divided into two small groups randomly, namely the group that received PCA intervention as the experimental group and the group that received conventional intervention as the control group. The purpose of random assignment is to eliminate all factors outside the intervention process that can affect differences between the two groups.

\subsection{Research Stages}

The stages of this research are as follows; First, conducting a research preparation involving several technical teams; Second, measuring the level of student behavior by using an aggressive behavior scale; Third, analyze the measurement results and determine students who have very high levels of aggressive behavior as research subjects; Fourth, the intervention process by dividing the research subjects into two groups, namely the control group and the experimental group; Fifth, conduct a post-test to measure differences in behavior after an intervention has been carried out; Sixth, conduct data analysis to compare the level of students' aggressive behavior before and after the intervention is given.

\subsection{Data Analysis Technique}

The data analysis technique used in this study was the independent t-test. This is done to test the comparison of conventional counseling, which is usually implemented by the counselor with PCA in reducing the aggressive behavior of students. The results of the comparison of the data are presented in a quantitative descriptive manner.

\section{Results}

\subsection{Stages of Intervention}

The PCA applied in this study uses six stages, which were adopted from several theories (Castro \& Nario-Galace, 2008; Fountain, 1999). The stages of PCA are as follows, namely (a) rational treatment; (b) explore the root of the problem; (c) reflection on the phenomenon of violence from various perspectives; (d) teach finding alternative behaviors; (e) look for different forms of violence and eliminate them; (f) evaluation and follow-up of peaceful thoughts, feelings and behavior. The six stages of the PCA use the grand theory of peace education.

In the first stage, the counselor explains the rational PCA to the counselee. This is done so that counselees can know and understand the reasons for the aggression behavior that they do need to be reduced, one of them by building peace of mind through the PCA. So, it is expected that the counselee can be cooperative, voluntary, and open to the counselor on the problem of aggression behavior.

In the second stage, the counselor explores the root causes of violence from various perspectives. Behavior carried out by students, is caused by errors of their thinking about aggression behavior patterns. At this stage, the counselor identifies how thought forms are driving the 
emergence of aggression behavior. The root of this problem is important to be known by counselors in the framework of adjusting the peaceful mind building intervention through PCA.

In the third stage, counselors reflect on the phenomenon of violence from various perspectives. At this stage, the counselor identifies how the counselee views the phenomenon of violence that occurs. The counselee's mistake in seeing the problem of violence will be the driving force for them to commit aggression, which they may not realize. This condition occurs because every human being has a destructive instinct, which in this case is the emergence of aggression behavior.

In the fourth stage, the counselor teaches the counselee to be able to find alternatives to violent behavior. Counselors provide specific cases of the phenomenon of violence that occurs. Based on the case, the counselor discusses with the counselee how to suppress the aggression behavior so that the aggression behavior in the case can be suppressed. This learning process is important in order that the counselee can internalize the way to make peace with himself and others when they are faced with situations that have the potential for aggression.

In the fifth stage, look for different forms of violence and eliminate them. At this stage, the counselor helps to make the counselee aware that the aggression behavior carried out is maladaptive behavior, and alternative behaviors need to be sought by channeling the aggression behavior impulse to something else. This can be useful to suppress the counselee's urge to hurt others and channel it to other positive things.

In the sixth stage, the counselor carries out an evaluation and follow-up to peaceful thoughts, feelings, and behavior. At this stage, the counselor identifies the things that the counselee has obtained during the counseling process. In addition, the counselor also makes a contract with the counselee to conduct further meetings in order to identify changes in behavior that occur after the counseling is implemented.

PCA can also be implemented in group settings. In this setting, the counselor utilizes group dynamics to implement PCA. Group dynamics are an important element of successful group counseling (Shechtman, 2017). PCA is implemented in a way between group members discussing and sharing to develop a peaceful mindset.

\subsection{Results of Data Analysis}

The results showed that there were differences in student aggression behavior between the groups given the PCA intervention and the conventional intervention group. Aggression behavior of students who were given PCA interventions decreased more significantly than control group students.

\section{Experimental Group}

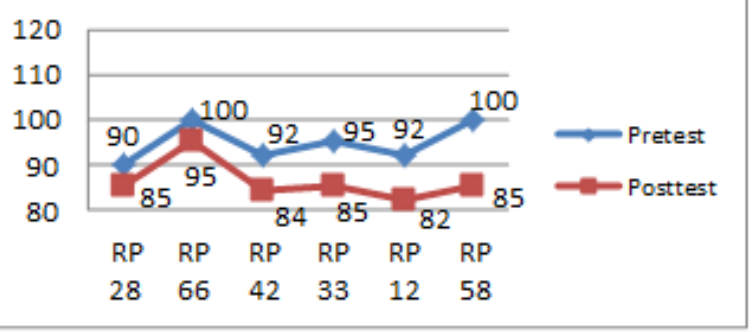

Figure 1. Comparison of pretest-posttest results of the experimental group

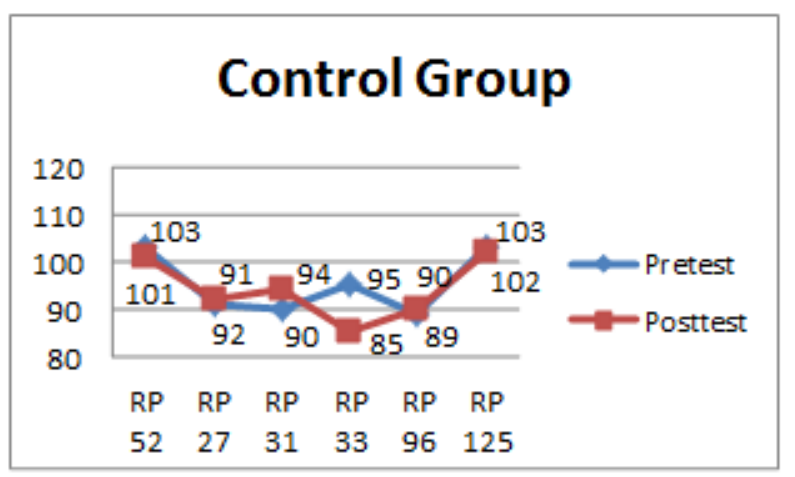

Figure 2. Comparison of pretest-posttest results of the control group

In figure 1 , it is explained in general that there is a decrease in the aggression behavior of the experimental group research subjects. RP28 subjects from the results of the analysis of the pretest instrument gained 90 decreased to 85 at the posttest. RP66 subjects from the results of the analysis of the pretest instrument gained 100 decreased to 95 at the posttest. RP42 subjects from the analysis of pretest instruments gained 92 decreased to 84 at the posttest. RP33 subjects from the results of the analysis of the pretest instrument gained 95 decreased to 85 at the posttest. RP12 subjects from the analysis of pretest instruments gained 92 decreased to 82 at the posttest. RP58 subjects from the analysis of the pretest instrument obtained 100 decreased to 85 at the posttest.

In figure 2, it is explained in general that there was a decrease in the aggression behavior of the dick group research subjects but it was less significant, in fact, there was one subject that increased. RP52 subjects from the analysis of pretest instruments gained 103 decreased to 101 at the posttest. RP27 subjects from the analysis of the pretest instrument gained 91 decreased to 92 at the posttest. RP31 subjects from the analysis of the pretest instrument gained 90 decreased to 94 at the posttest. RP33 subjects from the results of the analysis of the pretest instrument gained 95 decreased to 85 at the posttest. RP96 subjects from the analysis of pretest instruments gained 89 increased to 90 at the posttest. RP125 subjects from the analysis of pretest instruments gained 103 decreased to 102 at the posttest. 
Table 2. Average experimental and control groups

\begin{tabular}{|c|c|c|c|}
\hline & Group Type & N & Mean \\
\hline \multirow{2}{*}{$\begin{array}{c}\text { Aggression } \\
\text { Scores }\end{array}$} & Experiment Group & 6 & 86.0000 \\
\cline { 2 - 4 } & Control Group & 6 & 94.0000 \\
\hline
\end{tabular}

In table 2 , it can be interpreted that $\mathrm{N}$ is as much as 6 for each group. The mean of the experimental group was 86 and in the control group was 94.

Table 3. Results of the independent t-test analysis

\begin{tabular}{|c|c|c|c|c|c|}
\hline & \multicolumn{2}{|c|}{ Levene's Test } & \multicolumn{3}{c|}{ t-test } \\
\cline { 1 - 5 } & $\mathrm{F}$ & Sig. & $\mathrm{T}$ & $\mathrm{df}$ & $\begin{array}{c}\text { Sig. } \\
\text { (2-tailed) }\end{array}$ \\
\cline { 1 - 5 } $\begin{array}{c}\text { Equal variances } \\
\text { assumed }\end{array}$ & 1.053 & .329 & -2.457 & 10 & .034 \\
\hline $\begin{array}{c}\text { Equal variances not } \\
\text { assumed }\end{array}$ & & & -2.457 & 8.931 & .037 \\
\hline
\end{tabular}

In table 3, it appears that the $\mathrm{f}$ value obtained is 1.053 with a significance of 0.329 , which means it is greater than $0.05(0.329>0.05)$ so this means that the variant of the population group is homogeneous. Thus the homogeneity requirements for comparative analysis are met.

Furthermore, the results of the data analysis obtained the coefficient t-count of -2.457 with a probability of 0.034 when compared to 0.05 , the probability value is smaller, which means that there are differences in student aggression behavior between groups given PCA intervention and control groups. So it can be concluded that the aggression behavior of students who were given PCA interventions decreased more significantly than students who were given conventional interventions.

\section{Discussion}

The results of this study indicate that aggression behavior can decrease significantly after being given a PCA intervention. Students are able to develop peaceful thoughts that can minimize the desire of students to behave in aggression.

Some previous studies are in accordance with the results of this study, although there are no specific studies that have tested PCA. Research conducted in Turkey found that peace education can increase student empathy (Sagkal, Turnuklu, \& Totan, 2012). However, research conducted in Turkey uses the concept of education in general to develop empathy, while this research conceptualizes peace education, which is applied in PCM to reduce student aggression behavior. Empathy and aggression behavior are conceptually different, but several studies conclude that empathy is related to aggression (Barchia \& Bussey, 2011; Bock \& Hosser, 2014; Eisenberg, Eggum, \& Di Giunta, 2010; Kaukiainen,
Björkqvist, Lagerspetz, Österman, Salmivalli, Rothberg, \& Ahlbom,1999).

Another research result states that peace education supports students' desires in resolving conflicts without involving acts of violence such as aggression behavior (Carter, 2015). The research has a close relationship with this research, especially in conflict resolution without involving acts of violence, which of course is closely related to student aggression behavior. Students who have good conflict resolution have a tendency to be able to manage and control their aggressive behavior. However, this research is still limited to the use of the concept of peace education in general.

Peace education will also support the development of students' problem solving in resolving social conflicts they experience without using violence (Aarre, 2016). Problem solving in conflict resolution is related to aggression behavior. Students who have problem solving in good social conflicts have a tendency to manage and suppress aggressive behavior.

PCA can be used to help students reduce aggressive behavior. The implementation of PCA helps students to build peace in thinking. True peace exists in the human mind (Anand, 2014). This peace of mind can suppress the urge to show aggressive behavior.

In Indonesia, peace education is a vital necessity, because of the high behavior of aggression that arises. Peace education can be a model that is able to solve problems in Indonesia (Saputra, 2016). More specifically, this counseling approach can be used by counselors to develop peaceful thoughts in students so that they can regulate their emotions to reduce aggression behavior (Saputra \& Handaka, 2017).

Further research needs to be done in implementing PCA. In addition, cultural factors, gender, and other factors, need to be a separate study in the PCA.

\section{Acknowledgements}

The writers would like to express their gratitude to the Indonesian government, especially the Indonesian Directorate General of Higher Education (DIKTI), in funding this research.

\section{REFERENCES}

[1] Aarre, Anna. (2016). Effects of Peace Education and Grace and Courtesy Education on Social Problem-Solving Skills and Social Awareness. Retrieved from Sophia, the St. Catherine University repository website:https://sophia.stka te.edu/maed/188 .

[2] Alhadi, S., Purwadi, P., Muyana, S., Saputra, W. N. E., \& Supriyanto, A. (2018). Agresivitas Siswa SMP di Yogyakarta. Jurnal Fokus Konseling, 4(1). 
[3] Anand, S. (2014). The Contemporary Issues and Significance of Peace Education in India. International Journal of Research in Humanities, Arts and Literature, 2(10), 47-54.

[4] Aniței, M., Chraif, M., Burtaverde, V., \& Mihaila, T. (2014). The Big Five Personality Factors in the prediction of aggressive driving behavior among Romanian youngsters. International Journal of Traffic and Transportation Psychology, 2(1), 7-20.

[5] Barchia, K., \& Bussey, K. (2011). Predictors of student defenders of peer aggression victims: Empathy and social cognitive factors. International Journal of Behavioral Development, 35(4), 289-297.

[6] Berkowitz, L. (2012). A different view of anger: The cognitive-neoassociation conception of the relation of anger to aggression. Aggressive Behavior, 38(4), 322-333.

[7] Bock, E. M., \& Hosser, D. (2014). Empathy as a predictor of recidivism among young adult offenders. Psychology, Crime \& Law, 20(2), 101-115.

[8] Breuer, J., Vogelgesang, J., Quandt, T., \& Festl, R. (2015). Violent video games and physical aggression: Evidence for a selection effect among adolescents. Psychology of Popular Media Culture, 4(4), 305.

[9] Buss, A. H., \& Perry, M. (1992). The aggression questionnaire. Journal of Personality and Social Psychology, 63(3), 452.

[10] Cabezudo, A., \& Haavelsrud, M. (2013). Rethinking peace education. Journal of Conflictology, 4(1), 2.

[11] Carter, C. C. (2015). Standards and Guidelines that Influence Conflict and Peace Education. In The Contested Role of Education in Conflict and Fragility (pp. 187-201). New York: Springer.

[12] Duckworth, C. (2006). Teaching peace: A dialogue on the Montessori method. Journal of Peace Education, 3(1), 39 53.

[13] Edwards, B. D., Warren, C. R., Tubré, T. C., Zyphur, M. J., \& Hoffner-Prillaman, R. (2013). The validity of narcissism and driving anger in predicting aggressive driving in a sample of young drivers. Human Performance, 26(3), 191210.

[14] Eisenberg, N., Eggum, N. D., \& Di Giunta, L. (2010). Empathy-related responding: Associations with prosocial behavior, aggression, and intergroup relations. Social Issues and Policy Review, 4(1).

[15] Englehart, N. A. (2008). Resource conflict and ethnic peace in northern Thailand. Asia Pacific Viewpoint, 49(1), 98110.

[16] Floody, D. R. (2014). Serenity and inner peace: Positive perspectives. In Personal Peacefulness (pp. 107-133). New York: Springer.

[17] Galtung, J. (1967). Theories of peace: A synthetic approach to peace thinking. International Peace Research Institute, Oslo, 2(6).

[18] Haynes, N. M., Emmons, C., \& Ben-Avie, M. (1997). School climate as a factor in student adjustment and achievement. Journal of Educational and Psychological
Consultation, 8(3), 321-329.

[19] Kaukiainen, A., Björkqvist, K., Lagerspetz, K., Österman, K., Salmivalli, C., Rothberg, S., \& Ahlbom, A. (1999). The relationships between social intelligence, empathy, and three types of aggression. Aggressive Behavior: Official Journal of the International Society for Research on Aggression, 25(2), 81-89.

[20] Kovácsová, N., Rošková, E., \& Lajunen, T. (2014). Forgivingness, anger, and hostility in aggressive driving. Accident Analysis \& Prevention, 62, 303-308.

[21] Kutsyuruba, B., Klinger, D. A., \& Hussain, A. (2015). Relationships among school climate, school safety, and student achievement and well-being: A review of the literature. Review of Education, 3(2), 103-135.

[22] López, E. E., Pérez, S. M., Ochoa, G. M., \& Ruiz, D. M. (2008). Adolescent aggression: Effects of gender and family and school environments. Journal of Adolescence, 31(4), 433-450.

[23] MacNeil, A. J., Prater, D. L., \& Busch, S. (2009). The effects of school culture and climate on student achievement. International Journal of Leadership in Education, 12(1), 7384.

[24] Millon, A. M. H., \& Kawano, N. (2016). Do Peace Education Programs Have an Influence on High School Students?-Case Study of Hiroshima Jogakuin Jr. \& Sr. High School in Japan. 広島平和科学, 38, 127-141.

[25] Nazmie, I. F., Nebi, M. R., \& Zylfije Bekim, H. H. (2013). Poor executive functioning associated with the risk of aggressive behavior recidivism in the forensic community in schizophrenic patients. Int J BioMed, 3(2), 94-9.

[26] Noorfitriyani, L., Gunawan, D., \& Kertawidana, I. D. K. (2018). Pencegahan Perilaku Agresif: Pengaruh Pendidikan Perdamaian dan Literasi Media Terhadap Pemahaman Siswa Tentang Agresivitas. Damai Dan Resolusi Konflik, $4(1), 1-20$.

[27] Pong, S.-1., \& Zeiser, K. L. (2012). Student engagement, school climate, and academic achievement of immigrants' children. In C. G. Coll \& A. K. Marks (Eds.), The immigrant paradox in children and adolescents: Is becoming American a developmental risk? (p. 209-232).

[28] Qayyum, S., Malik, N., Iqbal, M. M. A., Haq, N. A., \& Malik, M. S. (2013). Exposure to Violent Television Programs and its Effect on Siblings Aggressive Behavior: Parents' Perceptions. International Journal of Business and Social Science, 4(7).

[29] Sagkal, A. S., Turnuklu, A., \& Totan, T. (2012). Empathy for Interpersonal Peace: Effects of Peace Education on Empathy Skills. Educational Sciences: Theory and Practice, 12(2), 1454-1460.

[30] Saputra, W. N. E. (2016). Pendidikan Kedamaian: Peluang Penerapan pada Pendidikan Tingkat Dasar di Indonesia. Jurnal CARE (Children Advisory Research and Education), 3(3), 88-94

[31] Saputra, W. N. E. (2018). Perilaku Agresi Pada Siswa SMK di Yogyakarta. Jurnal Fokus Konseling, 4(1).

[32] Saputra, W. N. E., \& Handaka, I. B. (2017). Konseling Kedamaian: Strategi Konselor untuk Mereduksi Perilaku 
Agresi Remaja. In Makalah dipresentasikan pada Prosiding Seminar Nasional Pendidikan Pancasila dan Kewarganegaraan III.

[33] Saputra, W. N. E., Hanifah, N., \& Widagdo, D. N. (2017). Perbedaan Tingkat Perilaku Agresi Berdasarkan Jenis Kelamin pada Siswa Sekolah Menengah Kejuruan Kota Yogyakarta. Jurnal Kajian Bimbingan Dan Konseling, 2(4), 142-147.

[34] Shapiro, S. (2015). Towards a critical pedagogy of peace education. Kultura-Spolleczeństwo-Edukacja, 7(1), 7-20.

[35] Shechtman, Z. (2017). Group counseling and psychotherapy with children and adolescents: Theory, research, and practice. Routledge.

[36] Shelton, D., Sampl, S., Kesten, K. L., Zhang, W., \& Trestman, R. L. (2009). Treatment of impulsive aggression in correctional settings. Behavioral Sciences \& the Law, 27(5), 787-800.

[37] Strohmeier, D., \& Spiel, C. (2003). Immigrant children in Austria: Aggressive behavior and friendship patterns in multicultural school classes. Journal of Applied School Psychology, 19(2), 99-116.

[38] Yusuf, I., \& Schmidt, L. P. (2006). Understanding conflict and approaching peace in Southern Thailand. Konrad Adenauer Stiftung. repository.au.edu.

[39] Yusuf, S. (2005). Mental Hygiene Perkembangan Kesehatan Mental dalam Kajian Psikologi dan Agama. Bandung: Pustaka Bani Quraisy. 